\title{
The Characterization of Steel Slag by Alkali Activation
}

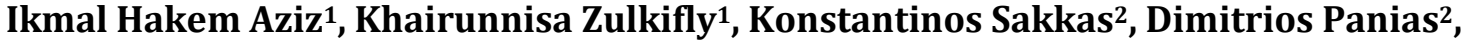 Georgia Maria Tsaousi², Mohd Mustafa Abdullah Al Bakri' ${ }^{1}$, Heah Cheng Yong1}

\author{
${ }^{1}$ Center of Excellence Geopolymer and Green Technology (CEGeoGTech), School of Materials Engineering, Universiti Malaysia \\ Perlis (UniMAP), Perlis, Malaysia \\ ${ }^{2}$ Department of Tunnelling, National Technical University Athens, Athens, Greece \\ Email: ikmalhakem@gmail.com, sakkas@metal.ntua.gr
}

How to cite this paper: Aziz, I.H., Zulkifly, K., Sakkas, K., Panias, D., Tsaousi, G.M., Al Bakri, M.M.A. and Yong, H.C. (2017) The Characterization of Steel Slag by Alkali Activation. Open Access Library Journal, 4: e3816.

https://doi.org/10.4236/oalib.1103816

Received: July 11, 2017

Accepted: November 10, 2017

Published: November 13, 2017

Copyright $\odot 2017$ by authors and Open Access Library Inc.

This work is licensed under the Creative Commons Attribution International License (CC BY 4.0).

http://creativecommons.org/licenses/by/4.0/

\begin{abstract}
This paper presents a characterization analysis of alkali-activated steel slag. The effect ratio of steel slag and ferronickel slag which are the precursor materials on the compressive strength of the alkali-activated materials was investigated. The combination of sodium hydroxide solution of 15 moles concentration and sodium silicate was used as an alkaline activator. The ratio between steel slag and alkaline liquid was fixed at 3.31 for all mixtures. Ambient curing $\left(20^{\circ} \mathrm{C}-25^{\circ} \mathrm{C}\right)$ are used throughout the experiment. Compressive strength shows the alkali-activated steel slag presented high strength at 14 days curing which is $21.56 \mathrm{MPa}$. In comparison, the alkali activated steel slag had better strength than 50/50 Fe/SS alkali-activated slag which only achieved 16.75 MPa. Result obtained shows that alkali-activated steel slag had better water absorption than 50/50 Fe/SS alkali-activated slag at 7 days curing. Furthermore, the activation of steel slag was contributed to the presences of gehlenite, larnite, akermanite and magnetite. Lastly, the alkali-activated steel slag presents the vibration of the Si-O bonds at wave number $970.46 \mathrm{~cm}^{-1}$ contributed by the calcium silicate hydrate.
\end{abstract}

\section{Subject Areas \\ Composite Material, Material Experiment}

\section{Keywords}

Steel Slag, Ferronickel Slag, Geopolymer, Amorphous Material

\section{Introduction}

Since the early of 1990s [1], alkali activated aluminosilicate-based material have 
been shown to exhibit a wide range of physical properties that allowing them to be applied in many industries. The potential of alkali activated material for the utilization in high temperature exposure has become one of the research interests. The use of this cementitious materials could also be used to reduce industrial waste for instance ashes [2] [3], slag [4] [5], water glass [6], copper mining [7] and others [8] [9]. Their versatilities possess many excellent engineering properties, including a high compressive strength and light weight. From past three decades, due to their superior properties that render them suitable in construction sector such as corrosion/fire resistant materials or as matrices for the encapsulation of hazardous elements including in aerospace industry [10] [11].

Alkali aluminosilicates mechanism appears to have main role in waste disposal. It could reduce permeability of the matrix and fixes certain ions in the structure of the phase formed [12]. Since 1950s, in Ukraine there are more than 100 certificates of invention and patents have been issued in the field of alkali-activated slag (AAS) [13] [14] [15]. The good prospect for the application of AAS has been discerned after abundant systematic studies published in English, Russian and Chinese [16] [17] [18]. Fundamentally, AAS cement is formed by the present of slag and an alkaline component. Slag waste consist the addition of sources of alkali fall within the system $\mathrm{Me}_{2} \mathrm{O}-\mathrm{MeO}-\mathrm{Me}_{2} \mathrm{O}_{3}-\mathrm{SiO}_{2}-\mathrm{H}_{2} \mathrm{O}$ and formed to be hybrid materials between "alkali-activated" and "alkaline" cements. The term "alkali-activated" is used by those $\mathrm{R}^{+}$(alkali) ions in such materials play catalytic role in the early stage, and then the zeolite-like phases will formed at later stage [19].

The potential of slag from the production of ferronickel in steel industry has been extensively investigated. Annual production of crude steel was estimated about 1.4 billion metric tonnes produced all over the world [20]. This manufacturing process produced a gigantic volume of waste called steel making slag [21]. Slag can be classified in two group which is coming from the ferrous (e.g. blast furnace slag, iron steel slag and ferroalloy slag) and non-ferrous metallurgy (e.g. lead, nickel, zinc, cadmium, tin, copper slag) [22]. However, the accumulation of this by-product of the steel production can leads to the environmental pollution plus the imbalanced reuse as a useful materials [23]. Therefore, in order to achieve sustainable development, the valorization of steel slag with appropriate physic-chemical, mechanical and thermal properties raise the interest to study further.

On the basis, there are two main models of alkali-activated binding systems. It can be classified as calcium-dominated (alkali-activated slag) and aluminosilicate-dominated (geopolymer) systems. In present study, a particular discussion on the chemistry of alkali activated binder dominated by high calcium allows it to function like OPC. Theoretically, the high calcium binder can be defined as a binder that have $\mathrm{Ca} /(\mathrm{Si}+\mathrm{Al})$ ratio of approximately to 1 , from the activation of blast furnace slag with alkaline solution. Alkaline activator act as the accelerator in this reaction as they assist the almost instantaneous hardening compared to 
the reaction with water which then leads to longer setting time and slow hardening [24]. Additionally, according Attis et al. [25] the final setting times can be reduced by increasing the sodium concentration of the activator. The instantaneous hardening when the slag is activated with alkali activators are due to the high rate of hydration reaction formed a desirable early strength paste structure that suitable for construction applications [26].

In succession, because of their properties and sustainability awareness in the industry majority of the Europe country including Spain has been adapting the potential use of slag in construction [27] [28]. Compared to Portland cement, AAS perform better in aggressive environments such as freeze-thaw cycles, chemical attack and high temperature [29] [30] [31]. Karahan et al. [31] studied the influence of activator types on the compressive strength of the AAS. Higher compressive strength is associated with the type of activator used in the synthesis. Sodium silicate and sodium metasilicate was found to have the best compressive strength in order of $100 \mathrm{MPa}$ at 28 days. Nonetheless, sodium hydroxide-activated slag achieves strength between 35 to $40 \mathrm{MPa}$ while maximum strength of $24.3 \mathrm{MPa}$ was developing by sodium carbonate-activated slag. According to Fernandez-Jimenez et al. [32], the lowest strength development by sodium carbonate alkaline activator is associated with a change in the morphology of the C-S-H. This, in turn, reduced the workability of the paste, resulting improper compaction during casting.

Moreover, extensive research have been carried out in order to study into deep the main factor apart of type of activators used that could affect the development of mechanical strength of AAS mortars and concretes [4]. There are few researchers claimed that by increasing the concentration of sodium [25] [33], mixing with $\mathrm{NaOH}$ [34] [35], or integrating waterglass [36] [37] [38] and introducing reactive admixtures such asMgO [39], lime [40] significantly can increase the mechanical strength. However, based on Bakharev et al. [41], at higher concentration of alkali or sodium silicates with modulus of solution, $\mathrm{M}_{\mathrm{s}}=1$, higher shrinkage and fast-setting cement was observed. Other researchers have indicated that fast setting cement must have an initial setting time of more than 5 min and a final setting time of less than $30 \mathrm{~min}$ [42]. According to this criteria, alkali-activated slag are quick-setting materials, whilst blended Portland/slag cements have slow-setting characteristics [41]. For that reason, AAS should rather be used as partial or full replacement of Portland cement.In fact, in 1995 Young has patent the utilization of steel slag as a raw material for cement product [43].

Thus, this paper provides information on the characterizations of steel slag which presence high amount of calcium and the comparison of blended steel slag and ferronickel slag. The main objectives of the study include the investigation to know the compressive strength, setting time, mineralogical characteristics and the properties obtained by the alkaline activation of the slag mixtures. 


\section{Experimental}

\subsection{Materials}

Steel slag and ferronickel slag was used as the aluminosilicate source in this alkaliactivated synthesis. The slag is siliceous materials that primarily consist of $\mathrm{CaO}$, $\mathrm{MgO}, \mathrm{SiO}_{2}$ and $\mathrm{FeO}$. The chemical compositions are highly variable and change depending on the raw materials, type of steel made and furnace condition. The slag used originated from the metallurgical plant of the Greek company LARCO G.M.M.S.A that treats laterites. The chemical analysis composition of the slag performed by XEPOS X-ray Fluorescene diffractometer utilizing X-LAB software is given in Table 1. The chemical components of steel slag have total $\mathrm{FeO}$ and $\mathrm{CaO}$ of $64.26 \%$. Whereas ferronickel slag has total $75.88 \%$ contain of $\mathrm{SiO}_{2}$ and $\mathrm{FeO}$. Sodium hydroxide $(\mathrm{NaOH})$ solution $(15 \mathrm{M})$ was used for the synthesis of inorganic polymers. The alkali solution was prepared by dissolving pellets of anhydrous $\mathrm{NaOH}$ (Merck, 99.5\% purity) in distilled water. The alkali solution was mixed with the water glass solution $(\mathrm{d}=1.296-1.396 \mathrm{~g} / \mathrm{ml})$ provided by Merck in order to produce the alkaline activator solution. The solid/liquid ratio was kept constant at $3.31 \mathrm{~g} / \mathrm{mL}$.

An adequate quantity of granulated slag was grinded to $-500 \mathrm{um}$ and the resulted powder has a mean particle size (d50) of 15.05 um, measured on a MALVERN Laser Particle Size Analyzer. The mineralogical analysis confirmed that steel slag used contains some trace amount minerals such as merwinite, gehlenite, akerminite and larnite.

\subsection{Experimental Procedure}

In order to synthesize alkaline activated material, steel slag and ferronickel slag was mixed with the alkaline activator in a mixer for 5 minutes until a homogeneous mixture was obtained. Then the mixture was molded in $50 \mathrm{~mm}$ open plastic (ERTASETAL) moulds. The resulted paste and its setting time was determined by a MATEST Vicat apparatus according to the EN 196-3:2005. The viscosity of the homogenous pastes was measured instantly subsequent their preparation by Brookfield Viscometer LV+. The sample was cured at ambient temperature until the day of testing.

The formulation of Fe-Ni slag and Steel slag (Fe/SS) has been designed as

Table 1. Chemical composition of steel and FeNi Slag.

\begin{tabular}{ccc}
\hline Chemical Composition & Steel Slag (wt\%) & FeNi Slag (wt\%) \\
\hline $\mathrm{SiO}_{2}$ & 13.65 & 41.14 \\
$\mathrm{Al}_{2} \mathrm{O}_{3}$ & 10.26 & 13.79 \\
$\mathrm{FeO}$ & 32.20 & 34.74 \\
$\mathrm{MgO}$ & 2.782 & 3.59 \\
$\mathrm{CaO}$ & 32.06 & 0.71 \\
$\mathrm{Ni}$ & 0.007 & 0.14 \\
\hline
\end{tabular}


Table 2. The formulation of SS/FeNi slag.

\begin{tabular}{ccc}
\hline Sample & Steel Slag & FeNi Slag \\
\hline AAS1 & 100 & 0 \\
AAS2 & 70 & 30 \\
AAS3 & 50 & 50 \\
AAS4 & 30 & 70 \\
\hline
\end{tabular}

shown in Table 2. There are four alkali-activated slag (AAS) prepared based on the ratio of Fe/SS slag. The formulation of Fe/SS slag was designed based on the ratio of $\mathrm{Si} / \mathrm{Al}=1.8$ and $\mathrm{Na} / \mathrm{Al}=1.00$ that suggested by Davidovits [42].

\section{Analysis and Test}

The comparison of phase characterization between AAS1, AAS2, AAS3, and AAS4 has been performed by using X-ray diffractometry (XRD) in order to detect the amorphous material The compressive strength were measured and comprised the average value of 3 samples according to ASTM C109 using the specimen of $50 \mathrm{~mm}$ edge. The mechanical properties performed on a testing machine of the Structural Behavior Engineering Laboratories Inc. (PTL-10 model) were measured at 1 day, 7 days, and 14 days after curing period.

The mineralogical characterization of alkali-activated slag (AAS) after the compressive test was performed by means of X-ray diffractometry (XRD) on a SIEMENS D58000 diffractometer. The FTIR measurement has been proposed to observe the movement of band that can present as well as the appearance of new band attributable to the formation of new chemical compounds. The infrared spectra were recorded in the region of $4000-800 \mathrm{~cm}^{-1}$ and collected using the Perkin Elmer 2000 analyser.

\section{Results and Discussion}

\subsection{Characterization Analysis}

1) FTIR Analysis

FTIR analysis was performed in order to see the potentially band forms through the alkali activation process of steel slag. Figure 1 shows the characteristic band of the alkali-activated slag (AAS1). It obtains the main absorption bands of steel slag as follows: 707.73, 843.17, 970.46, 1430, and $3183.3 \mathrm{~cm}^{-1}$. The major bands observed between 843.17 and $970.46 \mathrm{~cm}^{-1}$ represent the asymmetric stretching vibrations of the silica tetrahedral. Also, stretching and deformation modes of $\mathrm{OH}^{-}$at around $3183.30 \mathrm{~cm}^{-1}$ while asymmetric stretching mode of calcite at $1430 \mathrm{~cm}^{-1}$ are observed. The peak at $843.17 \mathrm{~cm}^{-1}$ are attributed to asymmetric stretching vibrations of the $\mathrm{SiO}_{4}$ tetrahedron and the vibration of $\mathrm{Al}-\mathrm{O}$ bonds with aluminum ions can be seen at $707.73 \mathrm{~cm}^{-1}$. The peak bands at 3183 $\mathrm{cm}^{-1}$ characterized the deformations vibrations of $\mathrm{OH}$ groups from the weakly bound water molecules. 


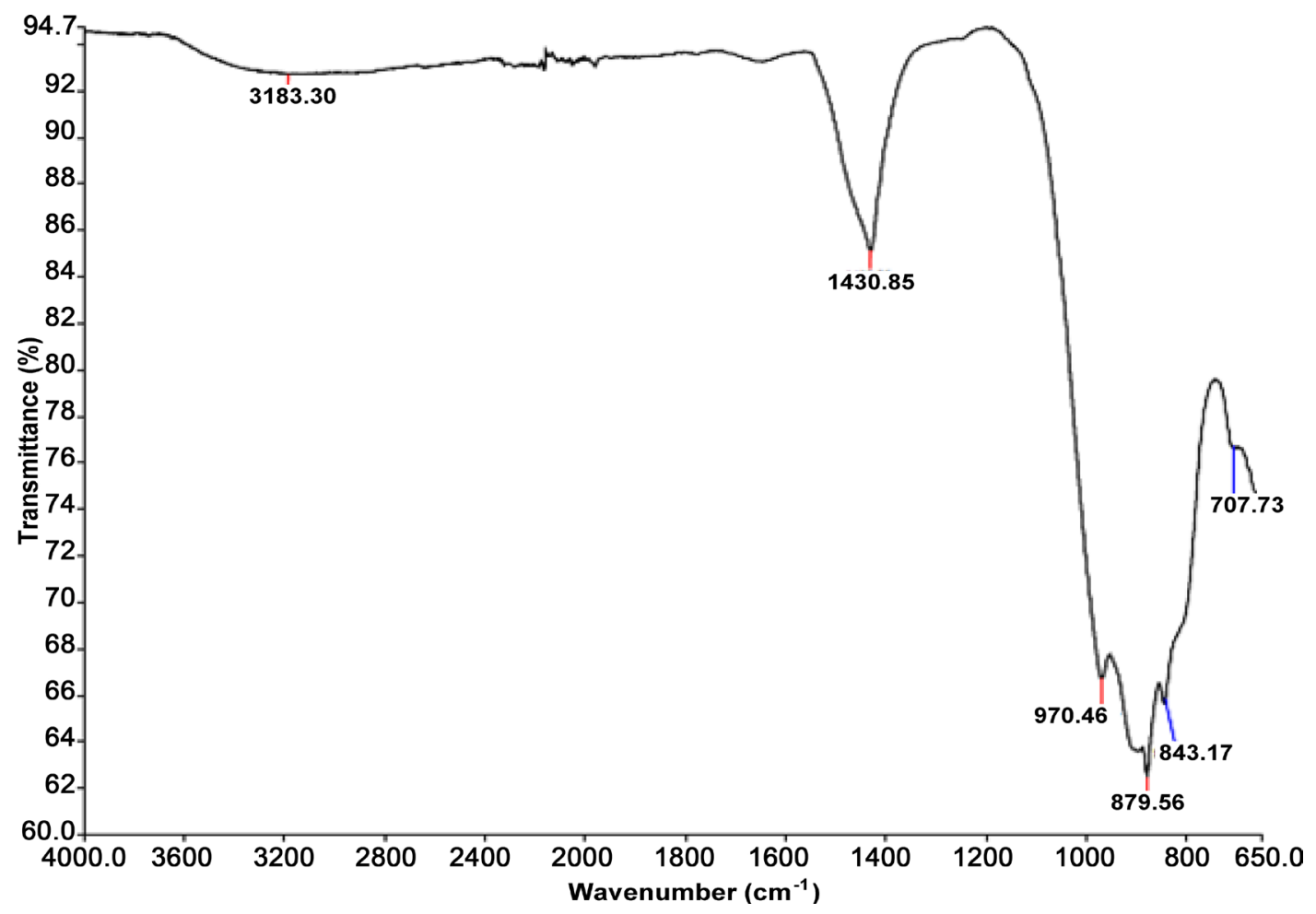

Figure 1. Fourier transforms infrared spectroscopy (FTIR) of the AAS1 cured at ambient temperature.

The activation of slag with sodium silicate generated the formations of C-(A)-S-H gel and hydrotalcite-like phase (co-existing with C-S-H depending on the $\mathrm{MgO}$ content of the slag) as the major reaction products [43] [44]. The calcium silica hydrate (C-S-H) systems, the Si-O-Si stretching bands are commonly observed in the range wavenumbers of 950 and $1000 \mathrm{~cm}^{-1}$ [45], related with a silica network that is highly polymerized and contribute to the development of higher mechanical strength [46]. The characteristic of AAS1 at peak bands of $970.46 \mathrm{~cm}^{-1}$ obtained as a result of carbonation and the important decalcification of the C-S-H gel [47]. Thus, the production of peak obtained causing steel slag can be formed as alkali-activated material.

2) XRD Analysis

$\mathrm{XRD}$ analysis of steel slag incorporating with ferronickel slag is investigated with the different ratio of the material (AAS1-AAS4) in order to produce the amorphous geopolymer material. The AAS1 results mainly constituted of merwinite $\left(\mathrm{Ca}_{3} \mathrm{Mg}\left(\mathrm{SiO}_{4}\right)_{2}\right)$, akermanite $\left(\mathrm{Ca}_{2} \mathrm{Mg} \cdot \mathrm{Si}_{2} \mathrm{O}_{7}\right)$, and larnite $\left(\beta-2 \mathrm{CaO} \cdot \mathrm{SiO}_{2}\right.$, $\left.\beta-\mathrm{Ca}_{2} \mathrm{SiO}_{4}\right)$. The XRD analysis obtained that alkali-activated steel slag mainly consisted of the metal oxides, silicates and aluminate forms that contributed to gehlenite and magnetite as the main reaction products. In addition, the activating steel slag in alkali solution exhibited the non-amorphous phase due to the presence of short range order of $\mathrm{CaO}-\mathrm{FeO}-\mathrm{SiO}_{2}-\mathrm{Al}_{2} \mathrm{O}_{3}$ structure within the materials.

The introduction of ferronickel slag in the alkali-activated slag modifies the XRD pattern which the characteristic of crystalline phases changes to low 


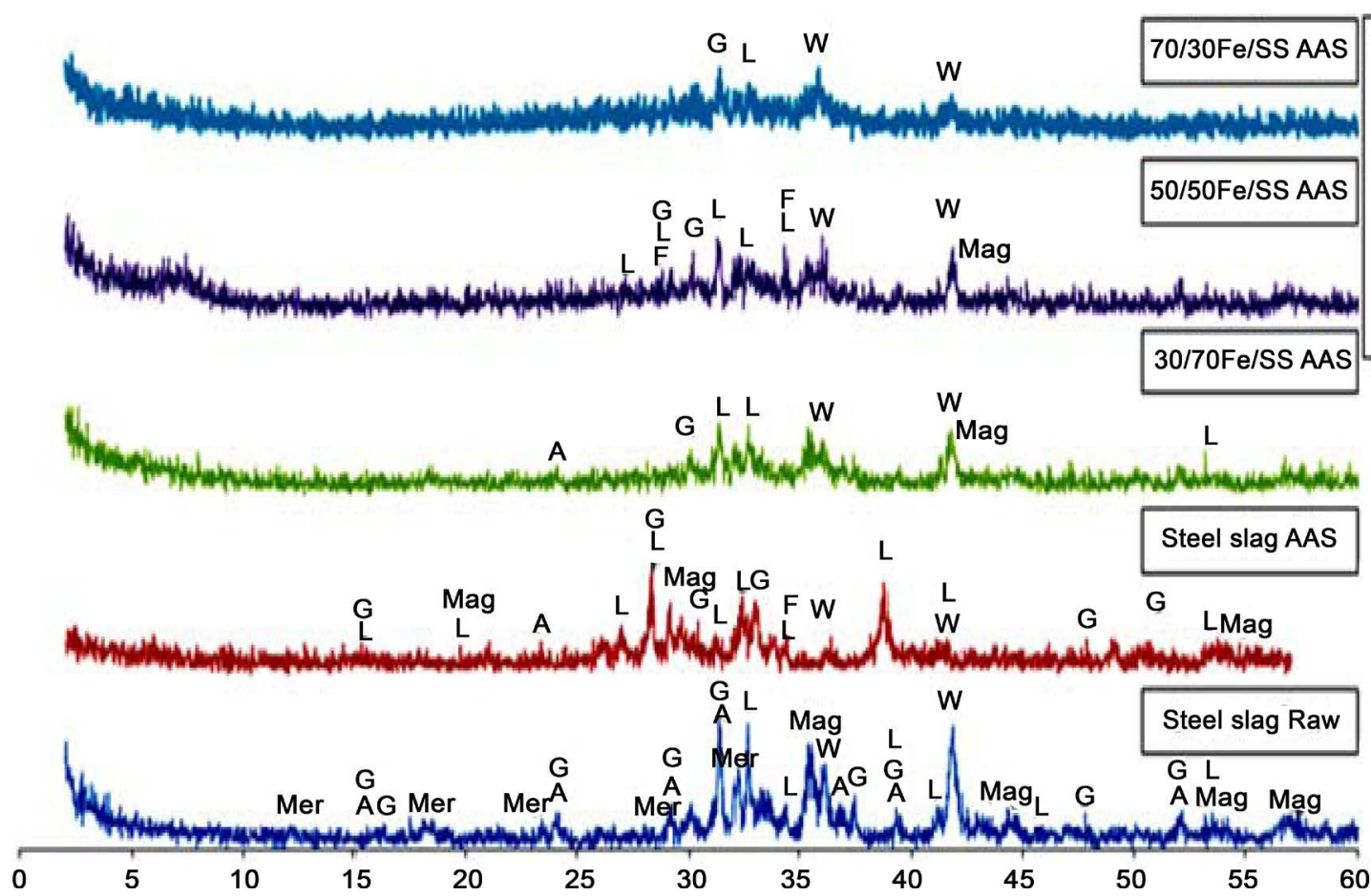

Figure 2. X-ray diffractogram of the alkali-activated slag in the five different formulations.

amorphous phases due to higher content of ferronickel slag in the mixture. Indeed, the $\mathrm{CaO}-\mathrm{Al}_{2} \mathrm{O}_{3}-\mathrm{SiO}_{2}$ system as crystalline phases corresponds to larnite and gehlenite. Gehlenite is one of the principal crystalline silica-containing phases in normal aluminous cements [48]. As shown in Figure 2, a weakly visible diffraction hump from $30^{\circ}$ to $35^{\circ} 2 \theta$ is present in AAS2, AAS3, and AAS4, thus indicating that alkali-activated slag with ferronickel is able to form an amorphous phases when it is activated by alkaline solution [49]. The evidence of C-S-H gel, usually identified by XRD with low intensity peaks between $30^{\circ}$ to $35^{\circ} 2 \theta$, is partially hidden by mayenite and gehlenite hydrate peaks [50]. Others, AAS3 generated the most amorphous phase with the intensity peaks from $5^{\circ}$ to $8^{\circ} 2 \theta$ as shown in Figure 2. Thus, AAS3 was selected for the further comparison study with AAS1 of steel slag.

Furthermore, it represents low amorphous material from a mixture of oxides of a relatively complex chemical composition. Such an example, wustite $(\mathrm{FeO})$, larnite $\left(\beta-2 \mathrm{CaO} \cdot \mathrm{SiO}_{2}, \beta-\mathrm{Ca}_{2} \mathrm{SiO}_{4}\right)$ and fayalite $\left(\mathrm{Fe}_{2} \mathrm{SiO}_{4}\right)$ are the most represented mineral phases detected in cement hydration mechanism [51] [52]. In contrary, the high amorphous of inorganic geopolymer obtained the dissolution of calcite due to presence of carbonate ions [53]. Besides, the calcium ions did not involves into the geopolymeric structure as sodium compounds was integrated in the amorphous geopolymeric phases [53].

\subsection{Physical and Mechanical Properties}

\section{1) Setting time}

Setting time was performed to determine the effect of ferronickel slag with 
alkali-activated steel slag. As shown in Figure 3, the setting times of the AAS1 were a final time of $30 \mathrm{~min}$, while the AAS3 were a final time of $60 \mathrm{~min}$. Indeed, setting time influenced by parameters such as particle size distribution and chemical composition of raw material used in the hydration process [54].

According to Figure 3(a), the AAS1 obtained a faster setting time due to higher of $\mathrm{CaO}$ content which is one of main chemical component of steel slag as shown in Table 1 . The $\mathrm{CaO}$ content in the slag material were accelerated the hydration reaction of the mixture [55]. In addition, the main factor that controls the setting time is the anion type of alkaline activator solution. These anions reacted with $\mathrm{Ca}^{2+}$ ions dissolves from slag, developing stable hydration products. Thus, in the existence of silicate ions forming an initial calcium silicate hydrate that accelerate the setting times and led to higher mechanical strength [56].

Figure 3(b) exhibited the AAS3 had longer setting time as $60 \mathrm{~min}$ due to the lower of $\mathrm{CaO}$ content in the precursor material. Tchakoute et al. [57] obtained the similar result in utilize the volcanic ashes for the production of geopolymer. Thus, the incorporating of ferronickel slag with alkali-activated steel slag delayed the setting time of the hydration process. As comparison, the alkali-activated steel slag showed the better setting time as cement hydration material.

\section{2) Water absorption properties}

Water absorption properties are important criteria in the application of the binders in construction. AAS1 and AAS3 exhibited comparable water absorption values at different curing period are presented as in Table 3 . The binder content of the alkali-activated slag material has particularly excellent effect on the water absorption properties of AAS1 which lower water absorption than the comparable AAS3 at 1 day until 7 days of curing. The result related to the water which
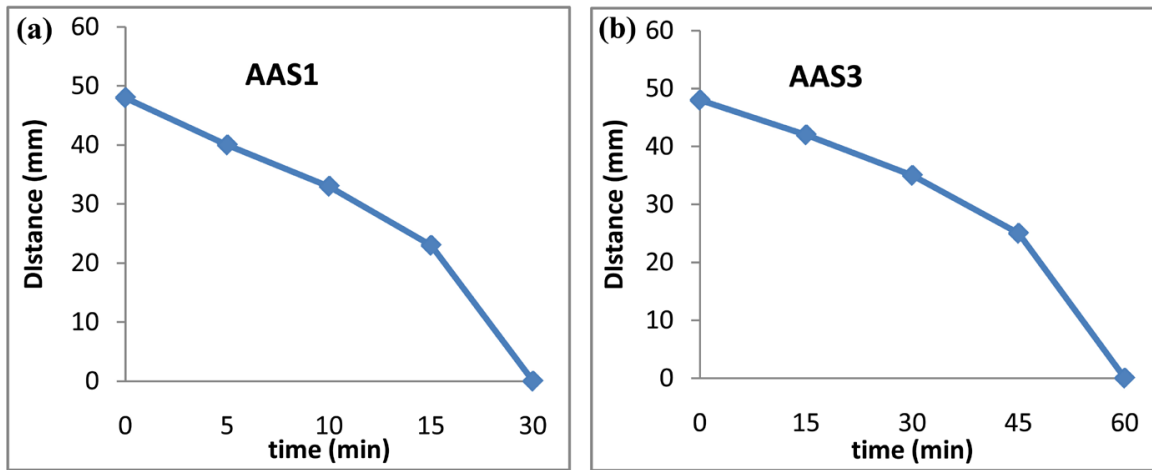

Figure 3. The comparison of setting time with (a) AAS1 and (b) AAS3.

Table 3. Absorption in alkali-activated slag with different content of binders.

\begin{tabular}{ccccc}
\hline & & \multicolumn{3}{c}{ Period of curing (day) } \\
\cline { 3 - 5 } Alkali-activated slag & Binder content $\left(\mathrm{kg} / \mathrm{m}^{3}\right)$ & \multicolumn{3}{c}{ Water absorption (wt\%) } \\
\cline { 3 - 5 } & & $\mathbf{1}$ & $\mathbf{3}$ & $\mathbf{7}$ \\
\cline { 3 - 5 } & 235.73 & 4.2 & 3.8 & 3.7 \\
AAS1 & 242.14 & 5.1 & 4.9 & 4.8 \\
\hline
\end{tabular}




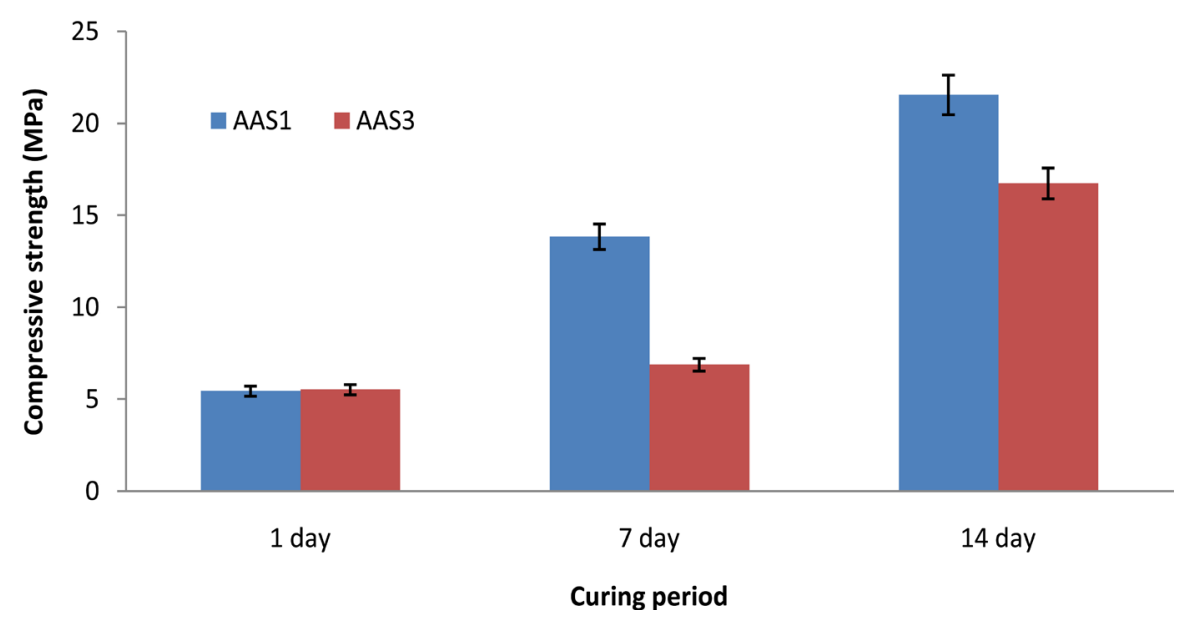

Figure 4. The compressive strength of AAS1 and AAS3 at different curing period.

does not readily penetrate, and also the ongoing formation of reaction products at advanced ages of curing [58].

3) Compressive strength

Figure 4 shows the compressive strength test result of AAS1 and AAS3 at 1 day, 7 days, and 14 days. The compressive strength of both alkali-activated slag at 1 day curing were approximately at 5.45 and $5.53 \mathrm{MPa}$, respectively. The compressive strength of AAS1 was slightly higher than AAS3 at 7 days and 14 days. The 14 days strength of AAS1 was $21.56 \mathrm{MPa}$ which the highest strength achieved among the comparable mixture with AAS3 that achieved the 14 days strength at $16.75 \mathrm{MPa}$. These results are similar with other studies that obtained the strength development of alkali activated slag increase with a larger amount of calcium in slag material [59] [60] [61], as a result of greater calcium dissolution and precipitation of C-A-S-H gel [62]. Thus, the formation of C-A-S-H provided the driving force to accelerate the chemical reaction that leads to shorter the setting time as presented in Figure 3(a). Also, with the formation of $\mathrm{C}-\mathrm{A}-\mathrm{S}-\mathrm{H}$ gel in the alkali-activated material due to increasing of calcium content was leads to enhance the strength as shown in Figure 4. In addition, the FTIR analysis proved that AAS1 produced the CSH product which resulted to the development of higher mechanical strength as shown in Figure 1.

\section{Conclusions}

X-ray diffraction phase analysis confirms that alkali-activated steel slag produced the non-amorphous material. Meanwhile, the incorporating of ferronickel slag in the alkali-activated steel slag exhibited low amorphous material.

The compressive strength of the AAS1 achieved the highest strength at 21.56 $\mathrm{MPa}$, showed that steel slag are preferable use as cement concrete material than AAS2, AAS3, and AAS4. Besides, it setting time of 30 min fully harden and excellent water absorption (3.7 weight\%) at 7 days curing. The FTIR and XRD analysis obtained the producing of $\mathrm{CSH}$ which influenced the properties of AAS1. 
In this study, it was proved that AAS1 was preferable used as concrete material due to excellent characterization and mechanical properties. Others, with some improvement and further study, AAS1 can be produced as lightweight or foam concrete material.

\section{Acknowledgements}

The authors gratefully acknowledge Center of Excellence Geopolymer and Green Technology (CEGeoGTech), School of Materials Engineering, UniMAP and National Technical University of Athens, Greece for their expertise and support. The authors would also like to thank for the funding support from the Fundamental Research Grant Scheme (FRGS-9003-00540) under Ministry of Education Malaysia (MOE) and support from "Partnership for Research in Geopolymer Concrete" (PRIGeoC-689857) sponsored by the European Union.

\section{References}

[1] Davidovits, J. (1991) Geopolymers. Journal of Thermal Analysis, 37, 1633-1656. https://doi.org/10.1007/BF01912193

[2] Temuujin, J., Van Riessen, A. and MacKenzie, K. (2010) Preparation and Characterisation of Fly Ash Based Geopolymer Mortars. Construction and Building Materials, 24, 1906-1910. https://doi.org/10.1016/j.conbuildmat.2010.04.012

[3] Chindaprasirt, P., et al. (2009) Comparative Study on the Characteristics of Fly Ash and Bottom Ash Geopolymers. Waste Management, 29, 539-543. https://doi.org/10.1016/j.wasman.2008.06.023

[4] Wang, S.-D., Scrivener, K.L. and Pratt, P. (1994) Factors Affecting the Strength of Alkali-Activated Slag. Cement and Concrete Research, 24, 1033-1043. https://doi.org/10.1016/0008-8846(94)90026-4

[5] Cheng, T. and Chiu, J. (2003) Fire-Resistant Geopolymer Produced by Granulated Blast Furnace Slag. Minerals Engineering, 16, 205-210. https://doi.org/10.1016/S0892-6875(03)00008-6

[6] Bădănoiu, A.I., Al-Saadi, T.H.A. and Voicu, G. (2015) Synthesis and Properties of New Materials Produced by Alkaline Activation of Glass Cullet and Red Mud. International Journal of Mineral Processing, 135, 1-10. https://doi.org/10.1016/j.minpro.2014.12.002

[7] Ahmari, S. and Zhang, L. (2012) Production of Eco-Friendly Bricks from Copper Mine Tailings through Geopolymerization. Construction and Building Materials, 29, 323-331. https://doi.org/10.1016/j.conbuildmat.2011.10.048

[8] Villa, C., et al. (2010) Geopolymer Synthesis Using Alkaline Activation of Natural Zeolite. Construction and Building Materials, 24, 2084-2090. https://doi.org/10.1016/j.conbuildmat.2010.04.052

[9] Zheng, G., et al. (2015) Alkali-Activation Reactivity of Chemosynthetic $\mathrm{Al}_{2} \mathrm{O}_{3}-2 \mathrm{SiO}_{2}$ Powders and Their $27 \mathrm{Al}$ and 29 Si Magic-Angle Spinning Nuclear Magnetic Resonance Spectra. Particuology, 22, 151-156.

https://doi.org/10.1016/j.partic.2014.10.006

[10] Cirpici, B.K., Wang, Y. and Rogers, B. (2016) Assessment of the Thermal Conductivity of Intumescent Coatings in Fire. Fire Safety Journal, 81, 74-84. https://doi.org/10.1016/j.firesaf.2016.01.011

[11] Vickers, L., Van Riessen, A. and Rickard, W.D. (2015) Fire-Resistant Geopolymers: 
Role of Fibres and Fillers to Enhance Thermal Properties. Springer, Berlin. https://doi.org/10.1007/978-981-287-311-8

[12] Roy, D. (1993) Advances and Applications in Cements/CBC's, Including Waste Management. Advanced Materials, 93.

[13] Glukhovsky, V., Rostovskaja, G. and Rumyna, G. (1980) High Strength Slag-Alkaline Cements. Proceedings of the 7 th International Congress on the Chemistry of Cement, Paris.

[14] Wang, S.-D. (1991) Review of Recent Research on Alkali-Activated Concrete in China. Magazine of Concrete Research, 43, 29-35. https://doi.org/10.1680/macr.1991.43.154.29

[15] Krivenko, P. (1992) Special Slag Alkaline Cements. Kyiv, Budivelnik.

[16] Glukhovsky, V. and Pakhomov, V. (1978) Slag-Alkali Cements and Concretes. Budivelnik Publishers, Russia.

[17] Pu, X., et al. (1988) Summary Reports of Research on Alkali-Activated Slag Cement and Concrete. Chongqing Institute of Architecture and Engineering, Chongqing, Vol. 1, 6.

[18] Mejía de Gutiérrez, R., et al. (2003) Durability of Mortars Made with Alkali Activated Slag. 11 th Congress on the Chemistry of Cement, Durban.

[19] Roy, D.M. (1999) Alkali-Activated Cements Opportunities and Challenges. Cement and Concrete Research, 29, 249-254.

[20] Association, E.S. (2006) Legal Status of Slags. Position Paper, January 2006.

[21] Directive, W.F. (2012) Position Paper on the Status of Ferrous Slag. Regulation.

[22] Provis, J. and Van Deventer, J. (2007) Geopolymerisation Kinetics. 2. Reaction Kinetic Modelling. Chemical Engineering Science, 62, 2318-2329.

[23] Atiş, C.D., et al. (2009) Influence of Activator on the Strength and Drying Shrinkage of Alkali-Activated Slag Mortar. Construction and Building Materials, 23, 548-555.

[24] Collins, F. and Sanjayan, J. (1999) Workability and Mechanical Properties of Alkali Activated Slag Concrete. Cement and Concrete Research, 29, 455-458.

[25] Rodríguez, A., et al. (2013) Design and Properties of Plaster Mortars Manufactured with Ladle Furnace Slag. Materials \& Design, 52, 987-994.

[26] Santamaría-Vicario, I., et al. (2015) Design of Masonry Mortars Fabricated Concurrently with Different Steel Slag Aggregates. Construction and Building Materials, 95, 197-206.

[27] Palacios, M. and Puertas, F. (2007) Effect of Shrinkage-Reducing Admixtures on the Properties of Alkali-Activated Slag Mortars and Pastes. Cement and Concrete Research, 37, 691-702.

[28] Neto, A.A.M., Cincotto, M.A. and Repette, W. (2008) Drying and Autogenous Shrinkage of Pastes and Mortars with Activated Slag Cement. Cement and Concrete Research, 38, 565-574.

[29] Karahan, O. and Yakupoğlu, A. (2011) Resistance of Alkali-Activated Slag Mortar to Abrasion and Fire. Advances in Cement Research, 23, 289-297. https://doi.org/10.1680/adcr.2011.23.6.289

[30] Fernández-Jiménez, A., et al. (2003) Structure of Calcium Silicate Hydrates Formed in Alkaline-Activated Slag: Influence of the Type of Alkaline Activator. Journal of the American Ceramic Society, 86, 1389-1394. https://doi.org/10.1111/j.1151-2916.2003.tb03481.x

[31] Bilim, C. and Atiş, C.D. (2017) Carbonation Resistance of Slag Mortars Activated by 
Different Alkali Activators. Turkish Journal of Engineering, 1, 1-4.

[32] Bakharev, T., Sanjayan, J. and Cheng, Y.-B. (2000) Effect of Admixtures on Properties of Alkali-Activated Slag Concrete. Cement and Concrete Research, 30, 1367-1374.

[33] Puertas, F. and Torres-Carrasco, M. (2014) Use of Glass Waste as an Activator in the Preparation of Alkali-Activated Slag. Mechanical Strength and Paste Characterisation. Cement and Concrete Research, 57, 95-104.

[34] Fernández-Jiménez, A. and Palomo, A. (2005) Composition and Microstructure of Alkali Activated Fly Ash Binder: Effect of the Activator. Cement and Concrete Research, 35, 1984-1992.

[35] Kovalchuk, G., Fernández-Jiménez, A. and Palomo, A. (2007) Alkali-Activated Fly Ash: Effect of Thermal Curing Conditions on Mechanical and Microstructural Development Part II. Fuel, 86, 315-322.

[36] Fernández-Jiménez, A., Palomo, J. and Puertas, F. (1999) Alkali-Activated Slag Mortars: Mechanical Strength Behaviour. Cement and Concrete Research, 29, 13131321.

[37] Abdalqader, A.F., Jin, F. and Al-Tabbaa, A. (2015) Characterisation of Reactive Magnesia and Sodium Carbonate-Activated Fly Ash/Slag Paste Blends. Construction and Building Materials, 93, 506-513.

[38] Kovtun, M., Kearsley, E.P. and Shekhovtsova, J. (2015) Chemical Acceleration of a Neutral Granulated Blast-Furnace Slag Activated by Sodium Carbonate. Cement and Concrete Research, 72, 1-9.

[39] Bakharev, T., Sanjayan, J.G. and Cheng, Y.-B. (1999) Alkali Activation of Australian Slag Cements. Cement and Concrete Research, 29, 113-120.

[40] Gan, M. (1997) Cement and Concrete. CRC Press.

[41] Young, R.D. (1995) Method and Apparatus for Using Steel Slag in Cement Clinker Production. Google Patents.

[42] Davidovits, J. (1994) Properties of Geopolymer Cements. 1st International Conference on Alkaline Cements and Concretes.

[43] Ravikumar, D. and Neithalath, N. (2012) Effects of Activator Characteristics on the Reaction Product Formation in Slag Binders Activated using Alkali Silicate Powder and $\mathrm{NaOH}$. Cement and Concrete Composites, 34, 809-818.

[44] Wang, S.-D. and Scrivener, K.L. (1995) Hydration Products of Alkali Activated Slag Cement. Cement and Concrete Research, 25, 561-571.

[45] García-Lodeiro, I., et al. (2008) FTIR Study of the Sol-Gel Synthesis of Cementitious Gels: C-S-H and N-A-S-H. Journal of Sol-Gel Science and Technology, 45, 63-72. https://doi.org/10.1007/s10971-007-1643-6

[46] Bernal, S.A., et al. (2011) Effect of Binder Content on the Performance of AlkaliActivated Slag Concretes. Cement and Concrete Research, 41, 1-8.

[47] Criado, M., Aperador, W. and Sobrados, I. (2016) Microstructural and Mechanical Properties of Alkali Activated Colombian Raw Materials. Materials, 9, 158. https://doi.org/10.3390/ma9030158

[48] Alper, A. (2012) Phase Diagrams 6-V: Materials Science and Technology. Vol. 5, Elsevier.

[49] Bignozzi, M.C., et al. (2013) Mix-Design and Characterization of Alkali Activated Materials Based on Metakaolin and Ladle Slag. Applied Clay Science, 73, 78-85.

[50] Pal, S., Mukherjee, A. and Pathak, S. (2003) Investigation of Hydraulic Activity of 
Ground Granulated Blast Furnace Slag in Concrete. Cement and Concrete Research, 33, 1481-1486.

[51] Rađenović, A., Malina, J. and Sofilić, T. (2013) Characterization of Ladle Furnace Slag from Carbon Steel Production as a Potential Adsorbent. Advances in Materials Science and Engineering, 2013, Article ID: 198240.

[52] Rungchet, A., et al. (2016) Hydration and Physico-Mechanical Properties of Blended Calcium Sulfoaluminate-Belite Cement Made of Industrial By-Products. King Mongkut's University of Technology North Bangkok. International Journal of Applied Science and Technology.

[53] Cwirzen, A., et al. (2014) The Effect of Limestone on Sodium Hydroxide-Activated Metakaolin-Based Geopolymers. Construction and Building Materials, 66, 53-62.

[54] Komnitsas, K. and Zaharaki, D. (2007) Geopolymerisation: A Review and Prospects for the Minerals Industry. Minerals Engineering, 20, 1261-1277.

[55] Provis, J.L. (2006) Modelling the Formation of Geopolymers Modelling the Formation of Geopolymers, The University of Melbourne.

[56] Fernández-Jiménez, A. and Puertas, F. (2003) Effect of Activator Mix on the Hydration and Strength Behaviour of Alkali-Activated Slag Cements. Advances in Cement Research, 15, 129-136. https://doi.org/10.1680/adcr.2003.15.3.129

[57] Tchakoute, H., et al. (2013) Utilization of Volcanic Ashes for the Production of Geopolymers Cured at Ambient Temperature. Cement and Concrete Composites, 38, 75-81.

[58] Bernal, S.A., et al. (2011) Evolution of Binder Structure in Sodium Silicate-Activated Slag-Metakaolin Blends. Cement and Concrete Composites, 33, 46-54.

[59] Lee, N. and Lee, H. (2013) Setting and Mechanical Properties of Alkali-Activated Fly Ash/Slag Concrete Manufactured at Room Temperature. Construction and Building Materials, 47, 1201-1209.

[60] Lee, N., Jang, J. and Lee, H. (2014) Shrinkage Characteristics of Alkali-Activated Fly Ash/Slag Paste and Mortar at Early Ages. Cement and Concrete Composites, 53, 239-248.

[61] Yao, X., Yang, T. and Zhang, Z. (2016) Compressive Strength Development and Shrinkage of Alkali-Activated Fly Ash-Slag Blends Associated with Efflorescence. Materials and Structures, 7, 2907-2918. https://doi.org/10.1617/s11527-015-0694-3

[62] Hojati, M. and Radlińska, A. (2017) Shrinkage and Strength Development of AlkaliActivated Fly Ash-Slag Binary Cements. Construction and Building Materials, 150, 808-816. 
Submit or recommend next manuscript to OALib Journal and we will provide best service for you:

- Publication frequency: Monthly

- 9 subject areas of science, technology and medicine

- Fair and rigorous peer-review system

- Fast publication process

- Article promotion in various social networking sites (LinkedIn, Facebook, Twitter, etc.)

- Maximum dissemination of your research work

Submit Your Paper Online: Click Here to Submit

Or Contact service@oalib.com 